\title{
EVALUASI MUTU SALEP DENGAN BAHAN AKTIF TEMUGIRING, KENCUR DAN KUNYIT
}

\author{
Titik Lestari, Bambang Yunianto, Agus Winarso \\ Kementerian Kesehatan Politeknik Kesehatan Surakarta Jurusan Jamu
}

\begin{abstract}
Quality Evaluation, Ointments, Kaemferia Galanga, Curcuma Domestica, Curcuma Heynena. Indonesia is a country with very high biodiversity. In the high diversity of the stored potential nutritious plants that can be explored and exploited further. Community began to realize the use of chemicals to cope with life problems, especially health problems, in addition to expensive, can also result in less side effects both for humans. This study used a extract Curcuma domestica, Kaemferia galanga, and Curcuma heynena as active ingredients skin ointments. This study intends to determine the third quality evaluation ointment. This type of research was descriptive. Quality evaluation results showed nearly the same physical properties, except for the parameters of the spread, and viscosity. Test result of physical standart compliant was organoleptic, $\mathrm{pH}$, power spread and viscosity.
\end{abstract}

Keywords: Quality Evaluation, Ointments, Kaemferia Galanga, Curcuma Domestica, Curcuma heynena

Abstrak: Sifat Fisik, Salep, Kunyit, Kencur, Temugiring. Indonesia merupakan negara dengan keanekaragaman hayati yang sangat tinggi. Keanekaragaman yang tinggi tersebut tersimpan potensi tumbuhan berkhasiat yang dapat digali dan dimanfaatkan lebih lanjut, salah satunya sebagai antimikroba. Masyarakat mulai sadar penggunaan bahan kimia untuk mengatasi masalah kehidupan, terutama masalah kesehatan, selain biayanya mahal, juga dapat mengakibatkan efek samping kurang baik bagi manusia. Penelitian ini menggunakan ekstrak kunyit, kencur, dan temugiring sebagai bahan aktif salep kulit. Penelitian ini bermaksud mengetahui evaluasi mutu tiga jenis salep. Jenis penelitian ini adalah deskriptif. Hasil evaluasi mutu menunjukkan sifat fisik yang hampir sama kecuali untuk parameter daya sebar, dan viskositas. Hasil evaluasi mutu yang sesuai standar adalah organoleptik, $\mathrm{pH}$, daya sebar, dan viskositas.

Kata Kunci : Sifat Fisik, Salep, Kunyit, Kencur, Temugiring

\section{PENDAHULUAN}

Indonesia merupakan salah satu negara tropis, memiliki keanekaragaman hayati yang tinggi, kaya akan flora dan fauna. Ribuan jenis tumbuhan berkhasiat obat tumbuh berkembang di Indonesia, yang harus dilestarikan dan dimanfaatkan dengan baik. Sebagian besar tumbuhan tersebut dapat digunakan sebagai tumbuhan berkhasiat obat. Tumbuhan berkhasiat obat yaitu tumbuhan atau bagian dari tumbuhan yang berupa daun, batang, buah, bunga dan akarnya yang memiliki khasiat sebagai obat, dan digunakan sebagai bahan mentah dalam pembuatan obat modern maupun obatobatan tradisional, salah satunya adalah salep (Peoloengan, 2006). 
Penelitian mengenai tumbuhan obat yang memiliki aktivitas antibakteri telah dilakukan sebelumnya baik secara sendiri-sendiri tiap jenis tumbuhan, maupun secara kombinasi dari beberapa jenis tumbuhan yang mempunyai aktivitas antibakteri, diantaranya adalah tumbuhan temu-temuan dari suku Zingiberaceae. Tumbuhan obat tersebut diantaranya adalah kunyit (Curcuma domestica), kencur (Kaempferia galanga L.) dan temugiring (Curcuma heyneana Val. \& v. Zijp). Kunyit mempunyai khasiat sebagai jamu dan obat tradisional untuk berbagai jenis penyakit. Kunyit mengandung senyawa aktif yaitu kurkumin dan minyak atsiri, mempunyai peranan sebagai antioksidan, antitumor, antikanker, antipikun, antiracun dan antimikroba. Tumbuhan kencur mengandung minyak atsiri, zat-zat yang sudah diketahui dari penelitian sebelumnya pada rimpangnya yaitu mengandung minyak atsiri $2,4 \%$ $3,9 \%$, juga cinnamal, aldehide, asam motil p-cumarik, asam annamat, etil asetat dan pentadekan. Rimpang kencur juga mengandung sineol, paraumarin, asam anisic, gom, pati $4,14 \%$ dan mineral 13,73\% (Rukmana, 1994 dalam Miranti, 2009).

Temugiring merupakan salah satu jenis rimpang yang memiliki manfaat yang sangat banyak dan beragam, salah satunya sebagai antimikroba, dan digunakan oleh masyarakat sebagai obat cacing dan obat gatal-gatal pada kulit (Heyne, 1987 dalam Charunia, 2009). Tiga tanaman obat tersebut mempunyai persamaan dalam kandungan minyak atsiri, minyak atsiri yang digunakan secara langsung dengan dioleskan pada permukaan kulit akan mudah menguap dan daya lekatnya kurang optimal, oleh karena itu perlu dibuat sediaan salep dengan menggunakan bahan aktif ketiga jenis tanaman obat tersebut sehingga mudah digunakan.

Salep adalah sediaan setengah padat yang mudah dioleskan dan digunakan sebagai obat luar, bahan aktif akan larut atau terdispersi secara homogen dalam basis salep yang cocok. Salep terdiri dari basis salep yang merupakan pembawa bersama kombinasi bahan aktif. Pembuatan salep agar berkhasiat sebagai obat, maka bahan obat harus terlepas dahulu dari basis salepnya (Idzon, et al., 1986 dalam Charunia, 2009). Salep memiliki keuntungan yaitu tidak mengiritasi, memiliki daya lekat dan distribusi yang baik pada kulit dan tidak menghambat pertukaran gas dan produksi keringat, sehingga efektivitasnya lebih lama (Voigt, 1984 dalam Charunia, 2009).

Penelitian ini bertujuan untuk mengetahui evaluasi mutu salep dengan bahan aktif ekstrak kunyit, kencur, dan temugiring.

\section{METODE PENELITIAN}

Jenis penelitian yang digunakan adalah deskriptif kuantitatif. Sampel dalam penelitian ini adalah salep dengan bahan aktif kunyit, kencur dan temu giring. Tehnik pengambilan sampel dengan purposive sampling dengan cara mengambil dari bagian pinggir sisi sebelah kiri, tengah dan pinggir sisi sebelah kanan salep dari ketiga wadah setiap jenis salep tersebut. 


\section{HASIL PENELITIAN}

Tabel 1

Evaluasi Mutu Salep dengan Bahan Aktif Temugiring, Kencur dan Kunyit

\begin{tabular}{|c|c|c|c|c|}
\hline \multirow{2}{*}{$\begin{array}{l}\text { No } \\
\text {. }\end{array}$} & \multirow{2}{*}{$\begin{array}{c}\text { Sub } \\
\text { Variabel }\end{array}$} & \multicolumn{3}{|c|}{ Salep dengan Bahan Aktif } \\
\hline & & $\begin{array}{c}\text { Temugiri } \\
\text { ng }\end{array}$ & Kencur & Kunyit \\
\hline 1. & $\begin{array}{l}\text { Organolept } \\
\text { ik }\end{array}$ & & & \\
\hline & - Warna & $\begin{array}{l}\text { Krem } \\
\text { gelap }\end{array}$ & $\begin{array}{l}\text { Krem } \\
\text { terang }\end{array}$ & $\begin{array}{l}\text { Kuning } \\
\text { pucat }\end{array}$ \\
\hline & - Bau & $\begin{array}{l}\text { Bahan } \\
\text { salep }\end{array}$ & $\begin{array}{l}\text { Bahan } \\
\text { salep }\end{array}$ & $\begin{array}{l}\text { Bahan } \\
\text { salep }\end{array}$ \\
\hline & - Rasa & $\begin{array}{l}\text { Dingin, } \\
\text { lembut }\end{array}$ & $\begin{array}{l}\text { Dingin, } \\
\text { lembut }\end{array}$ & $\begin{array}{l}\text { Dingin, } \\
\text { lembut }\end{array}$ \\
\hline 2. & $\begin{array}{l}\text { Homogenit } \\
\text { as }\end{array}$ & homogen & $\begin{array}{l}\text { homog } \\
\text { en }\end{array}$ & $\begin{array}{l}\text { homog } \\
\text { en }\end{array}$ \\
\hline 3. & Daya sebar & $\begin{array}{l}61,79 \\
\mathrm{~mm}\end{array}$ & $\begin{array}{l}63,56 \\
\mathrm{~mm}\end{array}$ & $\begin{array}{l}50,99 \\
\mathrm{~mm}\end{array}$ \\
\hline 4. & Daya lekat & $\begin{array}{l}01,60 \\
\text { detik }\end{array}$ & $\begin{array}{l}01,85 \\
\text { detik }\end{array}$ & $\begin{array}{l}01,65 \\
\text { detik }\end{array}$ \\
\hline 5. & $\mathrm{pH}$ & 6 & 6 & 6 \\
\hline 6. & Viskositas & $\begin{array}{l}39,000 \\
\text { cPa's }\end{array}$ & $\begin{array}{l}40.000 \\
\text { cPa's }\end{array}$ & $\begin{array}{l}37,500 \\
\text { cPa's }\end{array}$ \\
\hline
\end{tabular}

\section{PEMBAHASAN}

Penelitian ini menggunakan serbuk kunyit, kencur dan temugiring yang kemudian diekstraksi dengan metode maserasi. Ekstrak kental yang diperoleh dibuat sediaan salep. Hasil pengamatan organoleptis menujukkan bahwa bau ketiga jenis salep sesuai dengan bahan tambahan salep dan rasa dari ketiga jenis salep adalah dingin serta lembut, hanya warna salep yang berbeda yaitu salep dengan ekstrak temugiring berwarna krem gelap, salep dengan ekstrak kencur berwarna krem terang dan salep dengan ekstrak kunyit berwarna kuning pucat. Hasil uji organoleptis untuk bau dan rasa ketiga salep tidak ada perbedaan hanya pada warna salep yang berbeda disebabkan dari jenis bahan aktif yang digunakan. Hasil penelitian menunjukkan bahwa warna salep tergantung dari warna alami bahan aktif yang digunakan dan perbedaan organoleptis sediaan dikarenakan semakin besar konsentrasi ekstrak yang digunakan akan ada perbedaan warna serta aroma (Ulaen dkk, 2012; Rahayu 2016).

Hasil uji homogenitas menunjukkan susunan salep dengan 3 macam bahan aktif adalah homogen karena pada bagian atas, tengah dan bawah sediaan terdapat penyebaran partikel secara merata. Syarat sediaan yang baik adalah homogen (SNI, 1996). Sediaan yang homogen akan memberikan hasil yang baik karena bahan obat terdispersi dalam bahan setiap bagian sediaan mengandung bahan obat yang jumlahnya sama. Jika bahan obat tidak terdispersi merata dalam bahan dasarnya maka obat tersebut tidak akan mencapai efek terapi yang diinginkan.

Hasil daya sebar pada penelitian salep dengan 3 macam bahan aktif menunjukkan bahwa salep dengan bahan aktif temugiring adalah $61,79 \mathrm{~mm}$; salep dengan bahan aktif kencur adalah 63,56 mm dan salep dengan bahan aktif kunyit adalah 50,99 $\mathrm{mm}$. Evaluasi daya sebar dilakukan untuk mengetahui luasnya penyebaran salep pada saat dioleskan di kulit. Penelitian ini juga sesuai dengan penelitian Ulaen (2012), hasil daya sebar menunjukkan diameter 5,3 cm. Persyaratan daya sebar sediaan topikal sekitar 5-7 cm. Berdasarkan hasil uji daya sebar pada sediaan salep dengan 3 macam bahan aktif dapat dikatakan bahwa sediaan sudah memenuhi syarat daya sebar yang baik. Daya sebar yang baik menyebabkan kontak antara obat dengan 
kulit menjadi luas, sehingga absorbsi obat ke kulit berlangsung cepat.

Uji daya lekat merupakan salah satu pengujian yang dilakukan untuk mengetahui kekuatan salep melekat pada kulit, semakin lama salep melekat pada kulit maka semakin efektif. Hasil uji daya lekat pada penelitian ini menunjukkan salep dengan bahan aktif temugiring adalah 1,60 detik; salep dengan bahan aktif kencur 185 detik dan salep dengan bahan aktif kunyit 1,65 detik. Syarat waktu daya lekat salep yang baik adalah tidak kurang dari 4 detik. Hasil penelitian menunjukkan bahwa salep dari 3 macam bahan aktif belum memenuhi syarat waktu daya lekat yang baik, semuanya karena kurang dari 4 detik.

Berdasarkan hasil pengujian diketahui $\mathrm{pH}$ sediaan adalah $6, \mathrm{pH}$ tersebut memenuhi persyaratan $\mathrm{pH}$ sediaan topikal yaitu antara 4,5 - 6,5. Kulit yang normal memiliki $\mathrm{pH}$ antara 4,5 - 6,5 sehingga sediaan topikal harus memiliki $\mathrm{pH}$ yang sama dengan $\mathrm{pH}$ normal kulit tersebut, akan mempengaruhi penerimaan kulit terhadap sediaan. Sediaan topikal yang ideal adalah tidak mengiritasi kulit, iritasi kulit bisa terjadi bila sediaan salep terlalu basa atau terlalu asam. Hasil penelitian tidak sesuai dengan Ulaen (2012) hasil pengujian $\mathrm{pH}$ sediaan adalah 5 dan hasil tersebut juga masih sesuai dengan $\mathrm{pH}$ kulit normal.

Hasil uji viskositas menunjukkan ada perbedaan dari 3 jenis salep temu giring, kencur dan kunyit adalah 39.000 cPa's, 40.000 cPa's dan 37.500 cPa's. Nilai kisaran viskositas oleh SNI 16-43991996 yaitu berada dalam kisaran nilai viskositas 2000-50.000 cPa's. Salep dengan 3 bahan tersebut yang mempunyai viskositas tertinggi adalah salep kencur dan hasil viskositas dari ketiga salep tersebut sudah sesuai dengan standar. Hasil penelitian ini jauh berbeda hasil viskositasnya dengan penelitian Rahayu (2016) yang menunjukkan hasil viskositas dari 3 formulai salep adalah $5.900 \mathrm{Cp}$; $7.800 \mathrm{Cp}$ dan $9050 \mathrm{Cp}$.

\section{KESIMPULAN DAN SARAN}

Kesimpulan dari penelitian ini adalah ketiga jenis salep dengan bahan aktif ekstrak kunyit, kencur dan temugiring mempunyai evaluasi mutu yang relatif sama, dan ada sedikit perbedaan dalam viskositas dan daya sebar. Saran kepada peneliti selanjutnya untuk membuat formulasi salep yang lebih baik sehingga hasil salep yang sesuai dengan standar mutu salep.

\section{DAFTAR RUJUKAN}

Charunia, D., 2009. Formulasi Salep Minyak Atsiri Rimpang Temu giring (Curcuma heynena Val \& Zijp) dan Uji Aktivitas Candida albicans in vitro Menggunakan Basis Polietilenglikol 4000 dan Polietilenglikol 400. Skripsi. Universitas Muhammadiyah Surakarta. Surakarta.

Miranti, 2009., Pengaruh Konsentrasi Minyak Atsiri Kencur (Kaempferia galanga 1.) dengan Basis Salep Larut Air terhadap Sifat Fisik salep dan daya hambat Bakteri Staphylococcus aureus Secara In Vitro, Skripsi. Universitas Muhammadiyah Surakarta. Surakarta.

Peoloengan, M., dkk., 2006. Aktivitas Antimikroba dan Fitokimia dari beberapa Tumbuhan Obat. Seminar Nasional Teknologi Peternakan dan Veteriner. 
12 Jurnal Kebidanan Dan Kesehatan Tradisional, Volume 2, No 1, Maret 2017, hlm 1-59

Rahayu, S., 2016. Hubungan Perbedaan Konsentrasi Ekstrak Kunyit Putih (Curcuma mangga Val.) Terhadap Sifat Fisik Lotion. Prosiding Rakernas dan Pertemuan Ilmiah Tahunan Ikatan Apoteker Indonesia: 50-56.
SNI, 1996. SNI. 16-4399-1996. Dewan Standarisasi Nasional. Jakarta

Ulaen, SPJ., Banne, Y., Suatan, RA., 2012. Pembuatan salep Anti Jerawat Dari Ekstrak Rimpang Temulawak (Curcuma xanthorriza Roxb). Jurusan Farmasi Politeknik Kesehatan Kemenkes Manado. 